ENTREPRENEURSHIP AND SUSTAINABILITY ISSUES

ISSN 2345-0282 (online) http://jssidoi.org/jesi/ 2019 Volume 7 Number 1 (September)

http://doi.org/10.9770/jesi.2019.7.1(33)

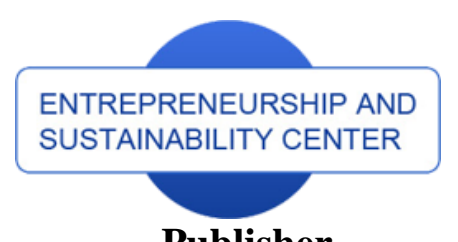

Publisher

http://jssidoi.org/esc/home

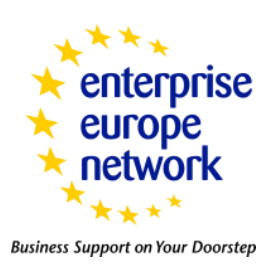

CASPA

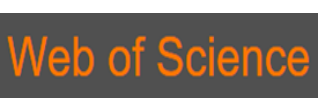

1 Clarivate

\title{
MODEL OF STATISTICAL ECONOMIC PROFILE OF INNOVATIVE BIOMEDICAL PRODUCT VALUE FORMATION AND UPDATE*
}

\author{
Irina Maslova $^{1 *}$, Boris Maslov ${ }^{2}$, Irina Korostelkina ${ }^{3}$, Liudmila Popova $^{4}$ \\ 1,2,3,4 Department of Economics, Finance And Accounting, Orel State University, \\ Komsomolskaya Str. 95, 302026 Orel, Russia \\ E-mail: ${ }^{1 *}$ professor-maslova@yandex.ru (corresponding author)
}

Received 12 March 2019; accepted 18 July 2019; published 30 September 2019

\begin{abstract}
Modern global science develops various concepts, theories, and models that have a certain value in different sectors of national economy. While there is a significant scientific foundation in the field of basic and applied research in biomedicine and biotechnology nowadays, this line has not gained proper momentum in economic terms. This concerns both formation of value, including value added, of innovative biomedical products and its accounting at the micro level, as well as innovation value formation and update at the government level. For these purposes, it is proposed to use statistical accounting as the basis for studying the quantitative side of innovative product value creation stages in the medical field. The purpose of statistical accounting is both to accumulate the most complete meaningful information and data characterizing essential conditions of these processes and their results and to create an information base for regulating the phenomena of added value formation and update in the field of biomedicine and analyzing their trends and patterns based on a system of interrelated quantitative and qualitative indicators. The article forms a macro- and mesostructure of a statistical economic profile of innovative biomedical product value formation and update and shows the level of cost blocks in groups of cost indicators of the profile. An equation for value formation in major elementary subprocesses was derived: full or partial employment of resources, formation of added value of a staple product, resources, and by-products. The proposed mathematical model is decomposed into three equation components: full and partial employment of resources as well as generation of all the elements of value added. Introduction of the authors' development would allow to ensure a systematic quantitative assessment of key aspects of the added value formation and update processes in the field of biomedicine.
\end{abstract}

Keywords: value added, innovation, costs, biomedicine, statistics

Reference to this paper should be made as follows: Maslova, I.; Maslov, B.; Korostelkina, I.; Popova, L. 2019. Model of statistical economic profile of innovative biomedical product value formation and update, Entrepreneurship and Sustainability Issues 7(1): 471-483. http://doi.org/10.9770/jesi.2019.7.1(33)

JEL Classifications: O31, G17, C15, C18

\footnotetext{
* The article was prepared while carrying out research work within the framework of the design part of the state assignment in the field of scientific activity in accordance with assignment No. 26.2758.2017 / 4.6 for 2017-2019. on the topic "The system of analysis of the formation and distribution of the cost of innovative products based on the infrastructure concept".
} 


\section{ENTREPRENEURSHIP AND SUSTAINABILITY ISSUES}

ISSN 2345-0282 (online) http://jssidoi.org/jesi/

2019 Volume 7 Number 1 (September)

http://doi.org/10.9770/jesi.2019.7.1(33)

\section{Introduction}

Today, the biomedical and biotechnology sector is an important area in modern post-industrial economy but its status in the world and in the Russian Federation has a dual character. On the one hand, developed countries are top producers of biotechnologies, while developing countries determine the demand for such products. The growth rate of global biotechnology market is about $10 \%$ per year. By 2020, it is planned to increase it to 600 billion dollars (Market Watch, 2014). On the other hand, world globalization is rapidly engaging developing countries in mass production. While $40 \%$ of the global commodity market in 2014 was made up of the USA, Europe, Canada, Australia, these days, countries of the Asia Pacific region, in particular, China, India, and Brazil, have significant market power. However, Russia still lags behind the leading countries both in the biopharmaceutical output indicator and the share of exports in the biotech production.

Emerging markets, including Russian, are marked with dependence on the import of foreign pharmaceutical products, as well as a shortage of innovative biotechnological products.

With regard to a complicated geopolitical situation and the effect of economic sanctions, Russia has begun to mainstream government projects to develop priority innovative industries. Nowadays, the modern biomedical industry in the Russian Federation is developing based on the Medical Science Development Strategy until 2025, which objectives are the medical research sector development, the domestic biomedicine integration into the global scientific and innovative environment, improvement of fundamental and applied research, ensuring a decent financing standard, and introduction of a medical science management system (Korostelkina et al., 2018).

Despite an increase in the investment activity of domestic producers and the import substitution policy (Vorotnikov et al., 2019) imported biotech drugs dominate the Russian market. Reasons for the lack of a sufficient number of innovative domestic medical drugs include a payback period of innovation and R\&D in biopharmaceutics, high risks, and lack of clear government regulation and distribution guarantees.

Effective development of the industry that serves as a guarantor of humanitarian well-being, national independence and a strategic guideline of state policy, as well as its sustainability and competitiveness in the world market should be ensured by a multidisciplinary nature of basic and applied research, development of new scientific and technological paradigms, and development of relevant industries. This, in turn, determines the incredibly rapidly growing global market for high-tech medical care with a huge demand for innovative products (knowledge, technology, products, etc.) (Public analytical report on the scientific-technological direction «Biomedicine», 2015).

At the same time, what is important is not only innovative development of bio-pharmacology, effective coordination of science, medicine and health care, but also public policies aimed at stimulating certain areas of the industry. Target orientation and purpose of government financing for state-of-the-art knowledge areas can be established through an integrated information system for accounting, analysis and control of performance indicators, which would serve as a communication mechanism between the state, business, science, and education.

Biomedical enterprises are marked by innovativeness of products with high added value that has to be kept track of, analyzed, evaluated and controlled for the purposes of updating and planning, creating innovative products by the pharmaceutical industry, and eliminating threats and external challenges for national biomedical research. 


\section{ENTREPRENEURSHIP AND SUSTAINABILITY ISSUES}

ISSN 2345-0282 (online) http://jssidoi.org/jesi/

2019 Volume 7 Number 1 (September)

http://doi.org/10.9770/jesi.2019.7.1(33)

Analysis of the size of updated added value of innovative products at the micro, meso and macro levels allows for an enterprise performance characteristic, for assessment of a region's situation and contribution to the national economy, as well as of the national economy in particular terms. Statistics of added value formation and update in the field of biomedicine is a rather important and significant section that serves both as a scientific activity and as a type of practical activity of state statistical authorities that ensures effective operation of other government agencies.

In this context, the development of applied statistics in terms of creating an economic profile for innovative biomedical product value formation and update would allow one to assess value (cost) indicators at different stages of creating the value of an innovative product-from an idea and its scientific development to commercialization at a startup or company level (in the financial accounting system) and the state (in the statistical accounting system). The proposed development builds up comprehensive information support for assessing the corporate and social value of innovation.

\section{Literature review}

The cost factor of innovation activity has always played a crucial role in the process of creating innovation. Any innovative product has a value and competitive advantages, whereby the manufacturer can influence consumers of the innovation and build its value. A cost is determined both by the enterprise itself, taking into account all the costs of creating and commercializing the product and a profit (micro level added value) and the government, whereby the activities of all the national economic sectors and their effectiveness are evaluated (macro level). While the added value of a PARTICULAR product can be calculated, analyzed and estimated using appropriate accounting practices and systems, the added value of innovations created in the state and on an industry-byindustry basis is difficult to estimate due to a lack of an integrated information system of statistical accounting.

Thus, our study covers not only the essence of innovation as such but also the issues of its cost accounting, forming and updating its added value and creating a statistical economic profile of innovative biomedical product value.

The issues of accounting and analysis of cost indicators gained serious scientific recognition in the $20^{\text {th }}$ century. Cost indicator accounting and methods of its analysis and evaluation were considered by Bentson (1982), Frolov and Maslova (2017), Popova et al. (2019) and others.

Innovative theories in the dynamic and evolutionary terms were developed by Schumpeter (1989), Drucker (2003), etc. The category of "innovation" is characterized by universality, a wide scope of application and complexity of its structural elements that have many approaches to its definition. According to Schumpeter (1989), it is innovations that are the "pivot of a new type of competition" and give rise to long business cycles. The scientist developed an innovative theory of long waves that was later integrated into the general innovation theory of economic development.

Drucker (2003) considers innovation as a socio-economic concept, identifying an improved return on invested resources as the goal of an innovative solution. Kleyner (1986) made a significant contribution to the study of innovation systems and innovation activities as well as factors that have a direct impact on the effectiveness of innovative development. 


\section{ENTREPRENEURSHIP AND SUSTAINABILITY ISSUES}

ISSN 2345-0282 (online) http://jssidoi.org/jesi/

2019 Volume 7 Number 1 (September)

http://doi.org/10.9770/jesi.2019.7.1(33)

However, innovations as such cannot and should not be considered in isolation from cost characteristics; therefore, many scientists, including Popova et al. (2019), Marenkov (2006), Rozhkova and Kutyleva (2014) propose specific mechanisms for innovative product value formation.

Global value chains (Kersan-Škabić, 2017; Tvaronavičienè, 2019) are explored internationally, including in the trade relations between the old world and the new EU member states, as well as the management of such chains (Frederick \& Gereffi, 2009; Koval et al., 2019) and evolution of the economic value added of managerial innovation in developing countries (Chiwamit et al., 2017; Aichele \& Heiland, 2018) derive structural equations for value-added trade flows on the basis of a multisectoral gravitational model with cross-sectoral links. In terms of industry, the cost of innovation in biomedicine is analyzed by Wesseler and Von Braun (2017). The scientists propose methods for measuring bioeconomy and analyze problems and drivers of its development. Detournay et al. (2018) identify the criteria and proposed and tested the model used by the French health care authorities to estimate the clinical value added (ASMR) of drugs, based on descriptive statistics and logistic models.

It is possible to estimate the cost of innovations using various methods that include both calculation (Udpa, 1996) and financial methods, for example, a discounted cash flow method, a weighted average capital cost estimate method (Luehrman, 1997) and others, including the authors' updated methods of present value estimate, which are appropriate to use under real-life conditions of innovation economy. Pulic (2000) refers VAIC method to such tools; it serves to measure and monitor the effectiveness of value creation using accounting indicators. Intellectual capital in the innovation cost estimate system plays a crucial role.

At the same time, the issues of statistical accounting of added value formation and update are not openly raised by either world or national science at present. González et al. (2018) explore the convergence of public accounting systems in the EU and offer an alternative to the current public accounting model based on an adjustment system. In this regard, the urgency and necessity of this research into statistical trends, including the cost of innovation industry's product, become obvious.

\section{Methodology}

The study appeals to the key aspects of the scientific problem, revealing the interaction of rationalistic and NeoPositivist empirical approaches. This will allow one to collect exhaustive information for analyzing and studying the issues of accounting and estimate of value added.

System approach is one of the most important conditions for comprehensiveness of a study, whereby the methods and tools for estimating the value added of innovative products in the biomedical industry are considered as a complex system and at the same time as an element of even more complex and larger-scale systems-innovative economy.

The systemic nature of added value formation and update statistics in the field of biomedicine involves consistency and completeness of indicators used to describe and analyze interrelated aspects of these processes.

To collect, to process and to analyze statistical data, the added value formation and update statistics in the field of biomedicine uses traditional statistical tools.

The research toolbox is composed of methods of structural-dynamic, comparative and statistical analysis, as well as of graphic scientific classification, simulation, and decomposition methods. The concepts of innovation and of the theory of value are fundamental theoretical background of the research. This study is underlain by socioeconomic comparative studies and interdisciplinary nature. 
The following will be used as methods of economic research: formal logic using analysis techniques, comparison and analogy in order to study the world practice and domestic experience of accounting cost indicators, as well as dialectics with the historical method to study the retrospective of statistical indicators of economic development of states. The use of these approaches and methods will allow us to propose a statistical economic profile of innovative biomedical product value. A systematic quantitative description of the main aspects of these processes should be provided from statistics on added value formation and update in the field of biomedicine.

\section{Discussion and results}

The basis for collection and aggregation of statistics on the processes and results of formation and update of the added value of innovative biomedical products is provided by a system of elementary statistical indicators that form a statistical economic profile of a process, a phenomenon, or a project.

The statistical economic profile of the processes of formation and update of the added value of innovative biomedical products, which is principally a model or a prototype serving to draw up a primary statistical accounting document, establishes the main information content describing a phenomenon.

The macrostructure of a statistical economic profile of innovative biomedical product value can be based on the following value assessment and information organization principles (Figure 1). Block 0 (moment constant) is required to create opportunities for comparing statistical data in time and space.

The value assessment concepts alongside with the accounting and reporting data ownership serve as fundamental bases for building an economic phenomenon profile structure.

A cost-based assessment concept that corresponds to accounting the added value formation in the field of biomedicine at different stages of creating value of an innovative product, from an idea and its research and development to commercialization, and makes it possible to evaluate and account the public value of innovation from the cost perspective at the state level.

A profit-based assessment concept that corresponds to accounting of the added value update in the field of biomedicine at different stages of creating value of an innovative product, from an idea and its research and development to commercialization, and makes it possible to evaluate the public value of innovation from the value perspective at the state level. 


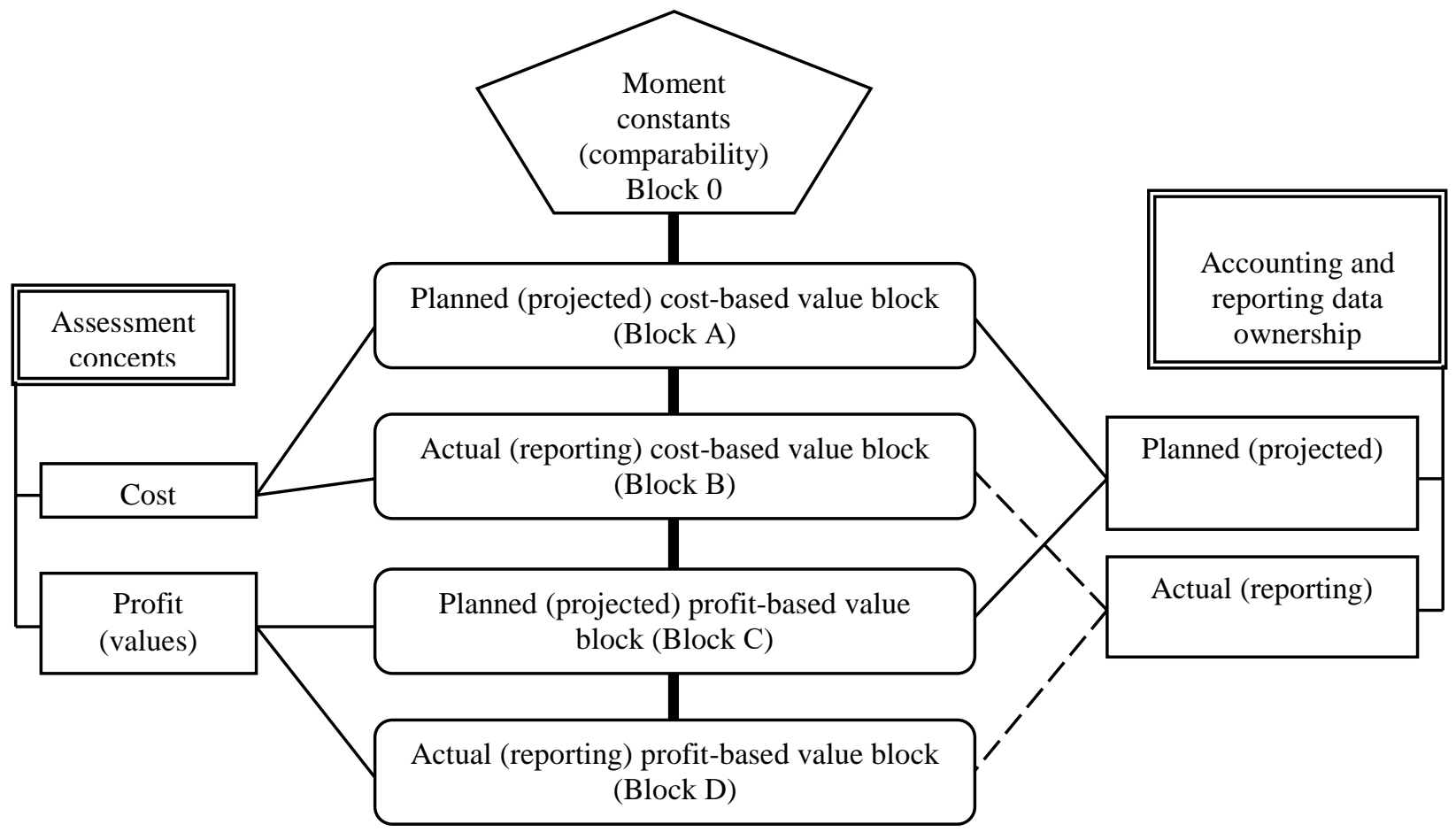

Fig.5. Macrostructure of a statistical economic profile of innovative biomedical product value formation and update

The combination of planned (projected) and actual (reporting or historical) values of indicators in the statistical economic profile of a phenomenon offers opportunities to improve the quality of planning and management of economic processes based on respective analysis, which ultimately improves the reliability of economic performance and its efficiency and offers prospects for optimizing their achievement in terms of resources expended, applied equipment and technologies, obtaining additional products and better fulfilling their value.

The mesostructure of individual blocks of the statistical economic profile of innovative biomedical product value formation and update is presented in Figure 2.

The moment constants serve as coefficients for reducing the cost and conditionally physical indicators arising in widely varying time or geographic conditions. The list of constants is non-exhaustive and its composition depends on the used and prospective methods to reduce indicators.

The mesostructure of the main planned and respective reporting blocks of the statistical economic profile of innovative biomedical product value formation and update is identical. That is, the nomenclature of groups of indicators in block $\mathrm{A}$ is the same as in block $\mathrm{B}$, and in block $\mathrm{C}$ it is the same as in block $\mathrm{D}$. 


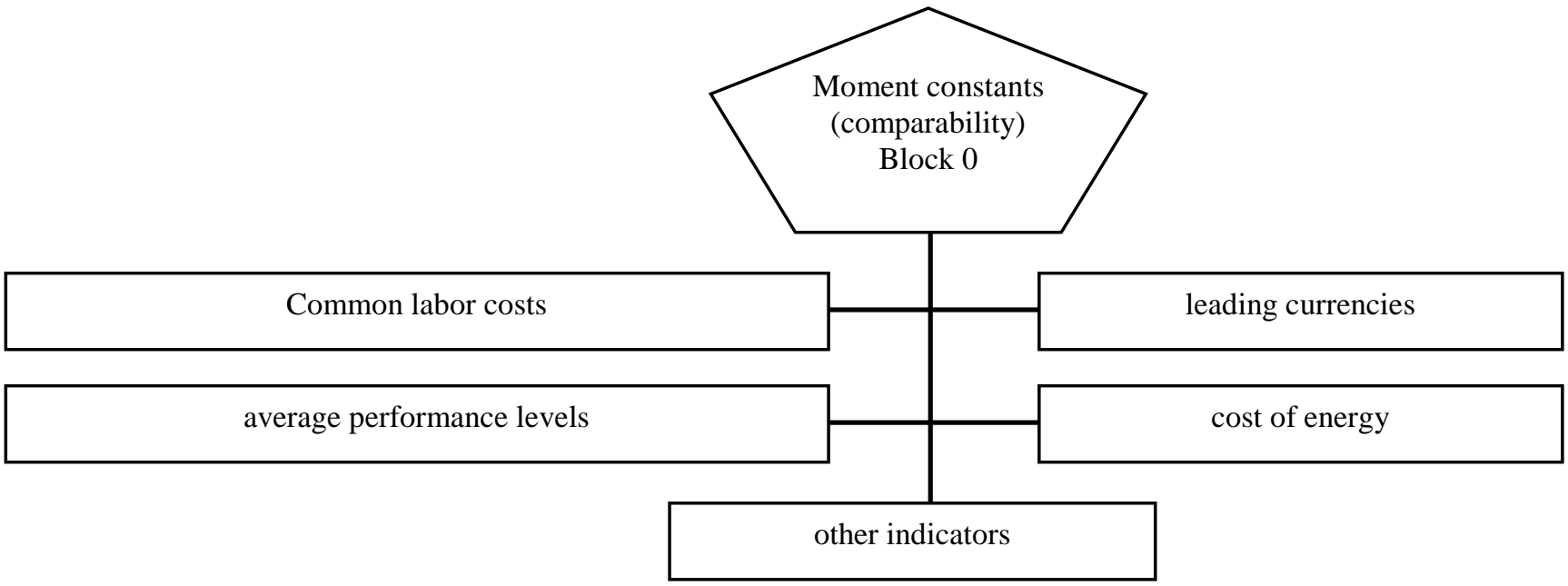

Fig. 2. Mesostructure of the statistical economic profile of innovative biomedical product value formation and update: Block 0Moment constants

Dramatic differences between the indicator group nomenclatures are caused by the orientation of the statistical economic profile sections in accordance with the respective concept of assessment. Thus, the cost component of the profile (blocks A and B) combines the following main groups of indicators of innovative biomedical product value and added value formation, detailed according to value creation stages (Figure 3).

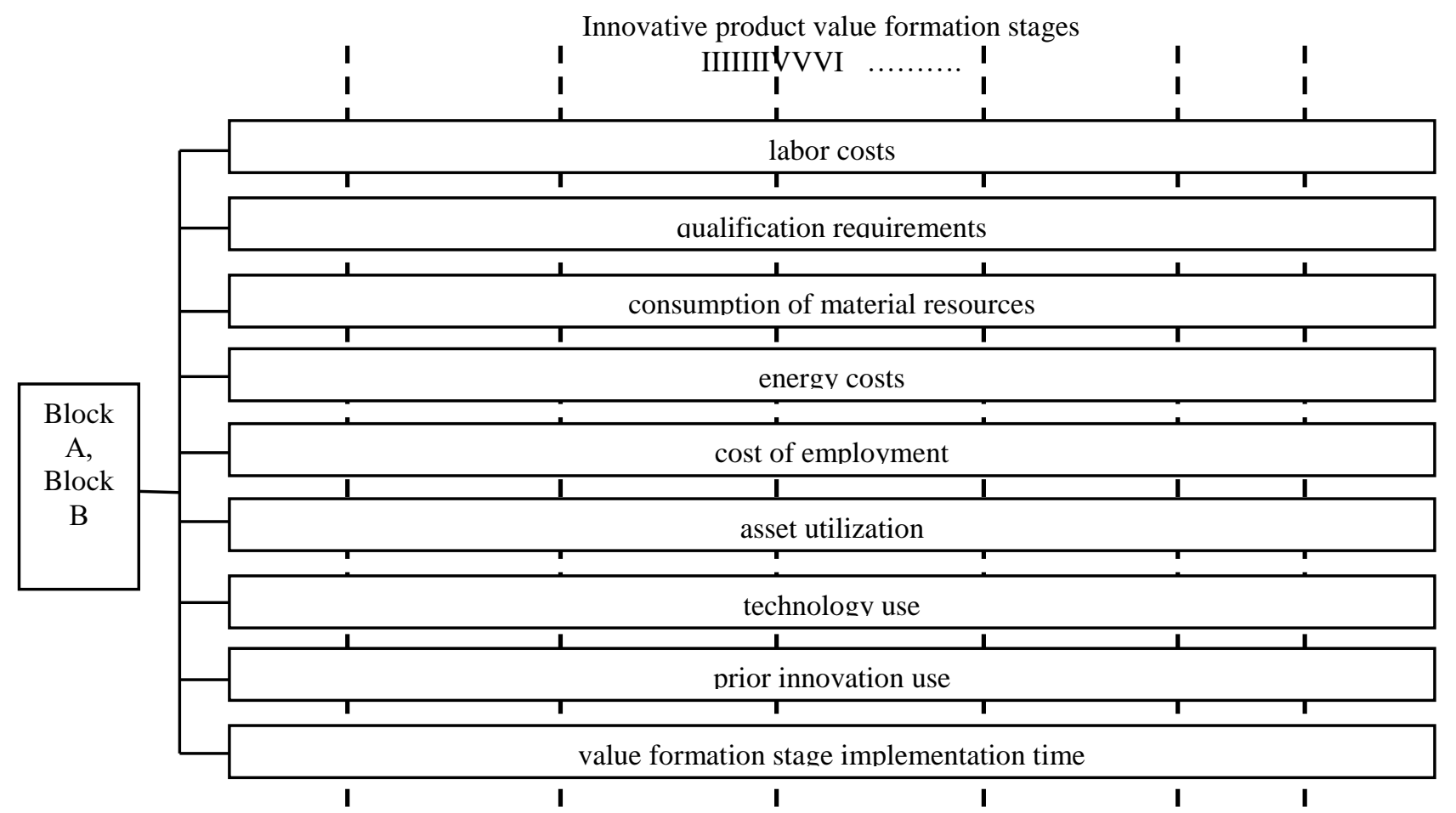

Fig. 3. Mesolevel of the cost block structure by groups of indicators in the statistical economic profile of innovative biomedical product value formation, including value added 
The most profound analyticity of data on cost-based value formation is achieved at the microlevel of the statistical economic profile structure in terms of value creation stages. The mesostructure is detailed down to the micro level-the level of elementary indicators on a component-by-component basis (Table 1).

Table 1. Detailed cost indicators at the mesolevel of statistical economic profile of innovative biomedical product value formation and its value added

\begin{tabular}{|c|c|c|}
\hline No. & Mesostructure & Indicators \\
\hline 1 & labor costs & $\begin{array}{l}\text { a) labor intensity; } \\
\text { b) number of personnel; } \\
\text { c) performance in natural and cost measures, etc. }\end{array}$ \\
\hline 2 & $\begin{array}{l}\text { qualification } \\
\text { requirements }\end{array}$ & $\begin{array}{l}\text { a) individual differentiation; } \\
\text { b) number of personnel; } \\
\text { c) differentiation by type of qualification; } \\
\text { d) differentiation by skill level; } \\
\text { e) achievements; } \\
\text { f) innovative discoveries; } \\
\text { g) qualification accumulation; } \\
\text { h) embedded foreign qualification holders; } \\
\text { i) labor intensity differentiated with respect to qualification; } \\
\text { j) personal and group performance in natural and cost measures }\end{array}$ \\
\hline 3 & $\begin{array}{l}\text { consumption } \quad \text { of } \\
\text { material resources }\end{array}$ & $\begin{array}{l}\text { a) differentiation with respect to types of material resources expended; } \\
\text { b) accounting of natural (quantity, quality) and cost characteristics of the material } \\
\text { resources expended; } \\
\text { c) identification of key production and technical characteristics of the material } \\
\text { resources expended }\end{array}$ \\
\hline 4 & energy costs & $\begin{array}{l}\text { a) differentiation with respect to types of resources expended; } \\
\text { b) accounting of natural (quantity, quality) and cost characteristics of the energy } \\
\text { resources expended; } \\
\text { c) identification of key production and technical characteristics of the energy } \\
\text { resources expended }\end{array}$ \\
\hline 5 & cost of employment & $\begin{array}{l}\text { a) cost of employment differentiated with respect to types of qualification; } \\
\text { b) employment cost differentiated with respect to skill levels }\end{array}$ \\
\hline 6 & asset utilization & $\begin{array}{l}\text { a) key operating characteristics of fixed assets used; } \\
\text { b) cost characteristics of fixed assets used; } \\
\text { c) depreciation of fixed assets }\end{array}$ \\
\hline 7 & technology use & $\begin{array}{l}\text { a) key operating characteristics of the technologies used; } \\
\text { b) cost characteristics of the technologies used; } \\
\text { c) technology use depreciation rates }\end{array}$ \\
\hline 8 & prior innovation use & $\begin{array}{l}\text { a) key production characteristics of the innovations used; } \\
\text { b) cost characteristics of the innovations used; } \\
\text { c) innovation use depreciation rates }\end{array}$ \\
\hline
\end{tabular}

The income component of the profile (blocks C and D) combines the following principal directions for formation of innovative biomedical product value update indicators and its added value indicators detailed by value creation stages (Figure 4). 


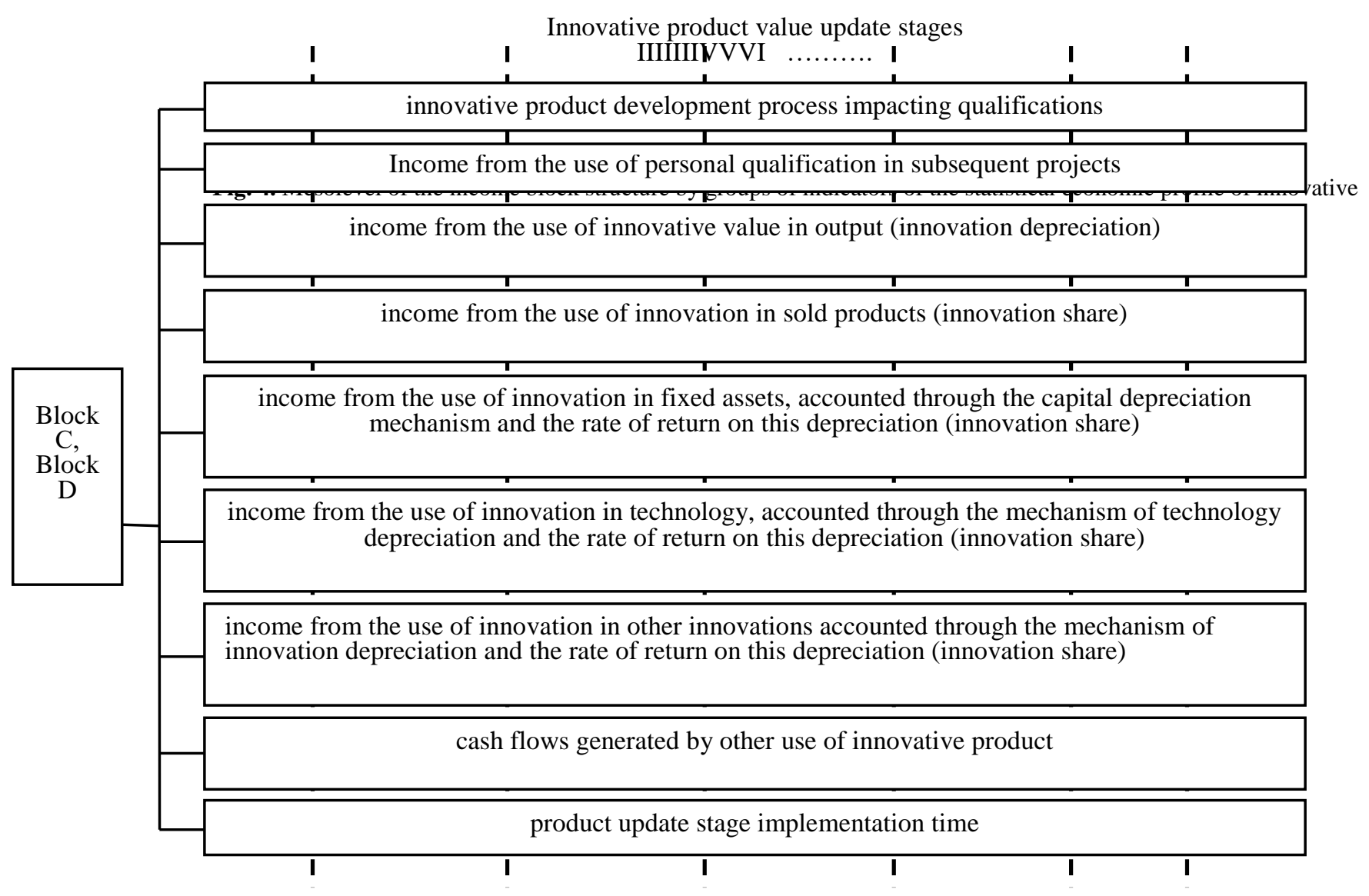

The integration of innovations into subsequent economic objects and processes should be taken into account in natural and cost measures.

Intersection of data in statistical economic profiles of projects for innovative biomedical product development, processes of value formation and update, profiles of personal qualification trajectories, and innovative product profiles will create conditions for checking data accuracy and reliability and comprehensive analysis of economic phenomena in the field of innovative biomedical product value and added value formation and update.

In order to develop a statistical accounting model for added value formation and update in the field of biomedicine, it is necessary to present a value formation equation. In the process of value formation for any object (product), a number of basic elementary subprocesses can be identified:

- full employment of resources;

- partial employment of resources;

- generation of value added and formation of an object value;

- generation of value added of the resources utilized;

- generation of scrap and by-product value.

In general, a value formation equation can take the form: 


$$
X=Y \text {, }
$$

where $X$ are components of the value used and the value added, $Y$ is the value obtained.

Full employment of a resource occurs when the resource utilized in the value creation process is totally consumed, transferring its value to an object (product). Examples of such resources are materials, some tools and implements, fuel and energy resources, etc. An equation with transfer of the value of a totally consumed resource in this case will be as follows:

$$
V w c i+X 0=V^{\prime}+Y 0,
$$

where $V w c i$ is the cost of the $\mathrm{i}$-th totally consumed resource, $X 0$ is the other components of the value used, $V^{\prime}$ is the resulting value of the object (product), $Y 0$ is the associated resulting value.

Grouping the cost of all the totally consumed resources, we obtain the first component of the equation:

$$
\sum_{i=1}^{n} V w c i
$$

and the equation with the first component takes the form:

$$
\sum_{i=1}^{n} V w c i+X 0=V^{\prime}+Y 0
$$

In the case of partial utilization of resources in the process of value creation, a resource cannot be fully employed but it transfers its value to the object (product) in the amount of its share, $\Delta V f a j$.

Similarly, a value transfer formula for partially utillized resources would be written as follows:

$$
\Delta V f a j+X 1=V^{\prime}+Y 0,
$$

where $\Delta V f a j$ is a share of the $\mathrm{j}$-th partially used resource value, $X 1$ is the other value components, $V^{\prime}$ is the resulting value of the object (product), $Y 0$ is the associated resulting value.

Grouping the cost of all the partially used resources, we obtain the second component of the equation:

$$
\sum_{j=1}^{n} V f a j
$$

where by the equation with the second component takes the form:

$$
\sum_{i=1}^{n} V w c i+\sum_{j=1}^{n} V f a j+X 2=V^{\prime}+Y 0
$$

Generation of value added that occurs as a result of physicochemical, informational and other resource transformations is normally initiated and carried out by informational elements of the value formation process, such as intangible assets, personnel qualification, and technology and innovation components. This generation is inseparable from the process of forming the value of an object (product) as such.

The elements that generate value added can be used, either fully or partially, thereby transferring their value to the object accordingly. This value transfer must be taken into account in the first and second components of the equation.

It should be noted that the elements of the process that generate value added often offer the property of increasing their own value (generating their own added value) as a result of their use. Some examples of those possessing such property may be personnel qualification, technology, innovation, and some types of intangible assets. 
Designating the generated added value of the object (product) as Vaddk, we obtain a formula that takes it into account during the object (product) value formation:

$$
\operatorname{Vaddk}+X 3=V^{\prime}+Y 0,
$$

where Vaddk is the value added by the k-th generating element, $X 3$ is the other cost components, $V^{\prime}$ is the resulting value of the object (product), $Y 0$ is the associated resulting value.

By grouping the value added by all the generating elements, we obtain the third component of the equation:

$$
\sum_{k=1}^{n} \operatorname{Vaddk}
$$

and the equation with the third component takes the form:

$$
\sum_{i=1}^{n} V w c i+\sum_{j=1}^{n} V f a j+\sum_{k=1}^{n} V a d d k+X 4=V^{\prime}+Y 0
$$

Obviously, the associated resulting value $Y 0$ similarly to $X$ can be divided into inherent value added of the resources used $V^{\prime} a d r$, scrap value $V^{\prime} w$, by-product value $V^{\prime} b p$, and other associated resulting value $Y 1$.

Thus, the object (product) value formation equation can be represented as:

$$
\sum_{i=1}^{n} V w c i+\sum_{j=1}^{n} V f a j+\sum_{k=1}^{n} V a d d k=V^{\prime}+V^{\prime} a d r+V^{\prime} w+V^{\prime} b p+Y 1
$$

The above equation fits into the framework of cost approaches to estimating the value of an object (product) and can be used in developing a statistical economic profile structure. However, it cannot claim to be an exhaustive description of value formation, since it must be solved in a system with an equation that would reflect incomebased approaches to determining the value range of an object (product). We hope to consider the equation for income-based approaches to estimating an object (product) value in our further publications.

\section{Summary}

Thus, the article reflects the main features of methodological model of added value formation and update accounting in the field of biomedicine at different innovative product value creation stages -from an idea and its scientific development to commercialization at the state level (statistical accounting), aimed at information support for assessing the corporate and public value of innovation based on identifying the innovation value formation and update stages depending on its type. A model of statistical accounting for added value formation and update in the field of biomedicine as an innovative product value formation equation, which is based on the cost approach, has been developed. The proposed model is appropriate to use when developing a statistical economic profile structure. 


\section{ENTREPRENEURSHIP AND SUSTAINABILITY ISSUES}

ISSN 2345-0282 (online) http://jssidoi.org/jesi/ 2019 Volume 7 Number 1 (September)

http://doi.org/10.9770/jesi.2019.7.1(33)

\section{References}

Aichele, R.; Heiland, I. 2018. Where is the value added? Trade liberalization and production networks, Journal of International Economics 115: 130-144. https://doi.org/10.1016/j.jinteco.2018.09.002

Bentson, G. 1982. Accounting numbers and economic values, Antitrust Bulletin 27: 161-215.

Chiwamit, P.; Modell, S.; Scapens, R. W. 2017. Regulation and adaptation of management accounting innovations: The case of economic value added in Thai state-owned enterprises, Management Accounting Research 37: 30-48. https://doi.org/10.1016/j.mar.2017.03.001

Detournay, B.; Borel, T.; Trancart, M.; Emery, C. 2018. Clinical added value of drugs: An empirical survey of French transparency committee opinions, Thérapie 2: 215-226. http://dx.doi.org/10.1016/j.therap.2018.10.004

Drucker, P.F. 2003. Management challenges for the 21st century. Moscow: Published by Publishing House «Williams».

Frederick, S.; Gereffi, G. 2009. Value chain governance. Washington, DC: United States Agency for International Development.

Frolov, A.; Maslova, I. 2017. Subject-independent modeling and representation data on the formation and distribution of innovative value, MATEC Web of Conferences 132: 04019. https://doi.org/10.1051/matecconf/201713204019

González, R.; Julve, V. M.; Bargues, J. M. 2018. Towards convergence of government financial statistics and accounting in Europe at central and local levels, Revistade Contabilidad-Spanish Accounting Review 21(2): 140-149. https://doi.org/10.1016/j.rcsar.2017.10.001

Kersan-Škabić, I. 2017. Trade in value added (TiVA) in EU new member states (EU NMS), Croatian Economic Survey 19(2): 105-133. https://doi.org/10.15179/ces.19.2.4

Kleyner, G. B. 1986. Production functions: theory, methods, application. Moscow: Published by Finance and Statistics.

Korostelkina, I. A.; Popova, L. V.; Dedkova, E. G. 2018. Study of the modern paradigm of innovative development of the national economy, Herald of Omsk University. Series «Economics» 4: 44-56. http://dx.doi.org/10.25513/1812-3988.2018.4.44-56

Koval, V.; Duginets, G.; Plekhanova, O.; Antonov, A.; Petrova, M. 2019. On the supranational and national level of global value chain management, Entrepreneurship and Sustainability Issues 6(4): 1922-1937. http://doi.org/10.9770/jesi.2019.6.4(27)

Luehrman, T. A. 1997. What's it worth? A general manager's guide to valuation, Harvard Business Review 75: $132-142$.

Marenkov, N. L. 2006. Methodological basis of innovative product valuation, Audit and Financial Analysis 1: 159-162. Retrieved from http://auditfin.com/fin/2006/1/Marenkov/Marenkov\%20.pdf

Market Watch. 2014. Retrieved from https://www.marketwatch.com

Popova, L.; Maslova, I.; Korostelkina, I.; Dedkova, E. G; Maslov, B. 2019. Value formation of innovative product: From idea to commercialization, Advances in Intelligent Systems and Computing 850: 331-338.

Public analytical report on the scientific-technological direction «Biomedicine». 2015. Retrieved from https://reestr.extech.ru/docs/analytic/reports/medicine.pdf

Pulic, A. 2000. VAIC - an accounting tool for IC management, International Journal of Technology Management 20: $702-714$. http://dx.doi.org/10.1504/IJTM.2000.002891

Rozhkova, N. K.; Kutyleva, N. M. 2014. The main approaches to the evaluation of the value of innovative product, Bulletin of the University 15: 143-148.

Schumpeter, J. A. 1989. History of economic analysis. Moscow: Published by Economics. Retrieved from http://www.urbanlab.org/articles/economics/Schumpeter\%201954\%20-\%20history\%20economic\%20analysis.pdf

Tvaronavičienè, M. 2019. Insights into global trends of capital flows’ peculiarities: emerging leadership of China, Administratie si Management Public (32): 6-17. http://doi.org/10.24818/amp/2019.32-01 


\section{ENTREPRENEURSHIP AND SUSTAINABILITY ISSUES}

ISSN 2345-0282 (online) http://jssidoi.org/jesi/ 2019 Volume 7 Number 1 (September) http://doi.org/10.9770/jesi.2019.7.1(33)

Udpa, S. 1996. Activity-based costing for hospitals, Health Care Management Review 21(3): 83-96. http://dx.doi.org/10.1097/00004010$\underline{199622000-00009}$

Vorotnikov, I. L.; Sukhanova, I. F.; Lyavina, M. Y.; Glukhova, M. I.; Petrov, K. A. 2019. Economic sanctions and import substitution, Entrepreneurship and Sustainability Issues 6(4): 1872-1883. http://doi.org/10.9770/jesi.2019.6.4(23)

Wesseler, J.; Von Braun, J. 2017. Measuring the bioeconomy: Economics and policies, Annual Review of Resource Economics 9: 275-298. https://doi.org/10.1146/annurev-resource-100516-053701

\section{Acknowledgement}

The article was prepared while carrying out research work within the framework of the design part of the state assignment in the field of scientific activity in accordance with assignment No. 26.2758.2017 / 4.6 for 2017-2019. on the topic "The system of analysis of the formation and distribution of the cost of innovative products based on the infrastructure concept".

Irina MASLOVA, doctor of economic Sciences, Professor, Professor, Department of Economics, Finance and accounting, senior researcher. Research interests: Finance, Economics, accounting, statistics. In 2006 he defended his doctoral thesis on "the System concept of accounting and value distribution in the post-transformation economy of Russia and its adaptation to international financial reporting standards" in the specialties 08.00.12 "Accounting, statistics" and 08.00.10 "Finance, money circulation and credit". The experience of scientific and pedagogical work in higher educational institutions is 18 years.

ORCID ID: orcid.org/0000-0002-3977-5247

Boris MASLOV, doctor of economic Sciences, Professor, Professor, Department of Economics, Finance and accounting, senior researcher. Research interests: Finance, accounting, statistics. In 2010 he defended his doctoral thesis on "Theory and methodology of analytical support of the state support of the agricultural sector on the basis of the concept of formation and distribution of value" in the field of 08.00.12 "Accounting, statistics" and 08.00.10 "Finance, money circulation and credit". Experience of scientific and pedagogical work in higher educational institutions since 2002.

ORCID ID: orcid.org/0000-0003-3849-8222

Irina KOROSTELKINA, doctor of economic Sciences, Professor, Professor, Department of Economics, Finance and accounting, senior researcher. Research interests: Finance, Economics, tax policy. In 2012 he defended his doctoral thesis on "the Concept of formation of structural parameters of multilevel tax policy" in the specialty 08.00.10 "Finance, money circulation and credit". The experience of scientific and pedagogical work in higher educational institutions is 16 years.

ORCID ID: orcid.org/0000-0001-6275-5466

Lyudmila POPOVA, doctor of economic Sciences, Professor, head of department of Economics, Finance and accounting, senior researcher. Research interests: Finance, accounting, In 1996 she defended her doctoral thesis on "Integrated system of accounting, analysis and audit in the economic mechanism of commercial enterprises" in the specialty 08.00 .12 "Accounting, statistics". Since 2000 - head of the Department "Accounting and taxation", as well as Chairman of the Council for the protection of theses for the degree of candidate and doctor of economic Sciences.

ORCID ID: orcid.org/0000-0003-2021-3348

Register for an ORCID ID:

https://orcid.org/register

Copyright (C) 2019 by author(s) and VsI Entrepreneurship and Sustainability Center

This work is licensed under the Creative Commons Attribution International License (CC BY).

http://creativecommons.org/licenses/by/4.0/

(c) (†) Open Access 